Tropical Journal of Pharmaceutical Research January 2014; 13 (1): 73-80

ISSN: $1596-5996$ (print); 1596-9827 (electronic)

(C) Pharmacotherapy Group, Faculty of Pharmacy, University of Benin, Benin City, 300001 Nigeria.

All rights reserved.

Available online at http://www.tjpr.org

Original Research Article

http://dx.doi.org/10.4314/tjpr.v13i1.11

\title{
Design and Development of Halogenated Chalcone Derivatives as Potential Anticancer Agents
}

\author{
Upendra K Jain ${ }^{1}$, Richa K Bhatia ${ }^{1}$, Akkinepally R Rao ${ }^{2^{*}}$, Ranjit Singh ${ }^{3}$, Ajit K \\ Saxena ${ }^{4}$ and Irum Sehar ${ }^{4}$ \\ ${ }^{1}$ Department of Pharmaceutical Chemistry, Chandigarh College of Pharmacy, Landran, Mohali, Punjab - 140307, \\ ${ }^{2}$ Pharmaceutical Chemistry Division, University College of Pharmaceutical Sciences, Kakatiya University, Warangal, A.P. - \\ 506009, ${ }^{3}$ School of Pharmaceutical Science, Shobhit University, Meerut, Uttar Pradesh - 250110, ${ }^{4}$ Cancer Pharmacology \\ Division, Indian Institute of Integrative Medicine, Jammu - 180001, India
}

*For correspondence: Email: raghumed@gmail.com, raghumed@kakatiya.ac.in; Tel: +91-870-244-6259; Fax: +91-870-2543508

Received: 18 November 2012

Revised accepted: 8 November 2013

\begin{abstract}
Purpose: To design and develop halogenated chalcone derivatives and evaluate them as anticancer agents using different cancer cell lines.

Methods: Based on in silico design and docking on known target, crystal structure of the complex of interleukin-1beta converting enzyme (ICE) with a peptide based inhibitor, (3S )-N-Methanesulfonyl-3(\{1-[N-(2-naphtoyl)-l-valyl]-I-prolyl\}amino)-4-oxobutanamide (1BMQ), novel halogenated chalcone derivatives were designed (7a-h) employing LigandFit module of Accelrys (Discovery Studio, 2.1 version). Standard protocols for ligand and protein preparation were employed and their binding orientation validated using (3S)-N-Methanesulfonyl-3-(\{1-[N-(2-naphtoyl)-I-valyl]-I-prolyl\}amino)-4oxobutanamide (MNO 601), a caspase inhibitor as reference standard. Energy minimized conformers with best dock scores were considered for the identification of interacting amino acid residues with ligands. Selected derivatives were synthesized and analyzed by melting point, ${ }^{1} H N M R$, IR and mass spectroscopy. Their evaluation for anticancer activity was carried out using adriamycin, paclitaxel and 5fluorouracil as reference standards on prostrate (PC-3), colon (COLO-205), ovary (OVCAR-5), liver (HEP-2) and neuroblastoma (IMR-32) cancer cell lines, and \% growth inhibition and half maximal inhibitory concentration $\left(I C_{50}\right)$ values were calculated.

Results: Among synthesized compounds, $7 \mathrm{~b}$ showed the most promising cytotoxic activity with an $I C_{50}$ of $49.9 \mu \mathrm{M}$ on colon cancer cell lines (Colo-205), followed by $7 d$ with an IC So $_{0}$ of $66.6 \mu \mathrm{M}$ against ovarian cancer cell lines (OVCAR-5).

Conclusion: We report the successful synthesis, spectral characterization and in vitro anticancer evaluation of a series of novel halogenated chalcone derivatives against a number of human cancer cell lines. The findings indicate the emergence of new anticancer compounds.
\end{abstract}

Keywords: Halogenated chalcones, Dock scores, Anticancer activity, Interleukin-1beta converting enzyme.

Tropical Journal of Pharmaceutical Research is indexed by Science Citation Index (SciSearch), Scopus, International Pharmaceutical Abstract, Chemical Abstracts, Embase, Index Copernicus, EBSCO, African Index Medicus, JournalSeek, Journal Citation Reports/Science Edition, Directory of Open Access Journals (DOAJ), African Journal Online, Bioline International, Open-J-Gate and Pharmacy Abstracts

\section{INTRODUCTION}

Chalcones constitute one of the important classes of anticancer agents that have shown promising therapeutic efficacy in the management of human cancers. They are considered as the precursors of flavonoids and isoflavonoids and are abundantly available in edible plants. They show a wide variety of activities, including anticancer [1], anti- 
inflammatory [2] and antiparasitic [3] activities. A number of modifications on chalcone chromophore have been reported including hydroxyl [4], methoxy [5], and amino [6] groups as substituents with promising anticancer activity.

A series of 4-hydroxy-6-methoxyaurones and 4, 6-dimethoxyaurones, which have binding affinity toward the nucleotide-binding domain of $\mathrm{P}$ glycoprotein, an ABC (ATP-binding cassette) transporter that mediates the resistance of cancer cells to chemotherapy, have been synthesized [7]. These compounds differ by the nature of the substituent on the aurone B-ring. The most active compounds were halogenated aurones: 4-bromo-4-hydroxy-6-methoxyaurone (1) and 4-hydroxy-4-iodo-6-methoxyaurone (2).<smiles>[X]c1ccc(/C=C2\Cc3cc(OC)cc(O)c3C2=O)cc1</smiles>

(1) $\mathrm{X}=\mathrm{Br}$<smiles>COc1cc(OC)c(C(=O)/C=C/c2ccc(I)cc2)c(OC)c1</smiles>

(3)

Further, they reported a strategy of opening ring $B$ to generate diaryl chalcones and succeeded in getting 2,4,6-trihydroxy-4-iodochalcone (3) with higher affinity with a $\mathrm{K}_{\mathrm{D}}$ value in nanomolar range [8].

A number of chalcone derivatives have been evaluated for multidrug resistance (MDR) reversal activity on mouse lymphoma cells and it was found that their activity decreased when the hydrophobicity of the substituent on ring $B$ was lowered, it is usually at 4-position (para to the carbonyl group) and the rank order of activity was found to be: chloro > dimethylamino > methoxyl group. One of them (4) exhibited activity at nanomolar concentrations in vitro [9].<smiles>COc1ccc(/C=C/C(=O)c2ccc(Cl)cc2)cc1OC</smiles>

(4)
These observations prompted us to design and synthesize halogenated chalcone derivatives based on in silico modeling and docking on known target $1 \mathrm{BMQ}$ and evaluated for their anticancer activity on different cell lines.

\section{EXPERIMENTAL}

\section{Software tools}

Molecular modeling was performed using Dell Precision work station T3400 running Intel Core2 Duo Processor, 4GB RAM, 250 GB hard disk, and NVidia Quodro FX 4500 graphics card. The software tool employed for the study was LigandFit module of Accelrys (Discovery Studio 2.1 version) [10].

\section{Materials and equipment}

Starting materials, reagents and solvents were purchased from commercial suppliers and purified/distilled/crystallized before use. All the melting points were recorded in open glasscapillaries on a Veego MP-D digital melting point apparatus and are uncorrected. Bruker Avance II (400 MHz) Nuclear Magnetic Resonance (NMR) spectrometer was used to record ${ }^{1} \mathrm{H}$ spectra. Chemical shifts $(\delta)$ are reported as downfield displacements from Tetramethylsilane (TMS) used as internal standard. Infrared (IR) spectra were recorded with Shimadzu FT-IR-8400S spectrophotometer on $\mathrm{KBr}$ pellets. Mass spectra (ESI-method), were recorded on Bruker Daltonics Esquire 300 mass spectrometer.

\section{Molecular modeling studies}

\section{Design of ligands}

The design of the target molecules was based on docking studies with the intention to gain an insight into the binding mode of the most active compounds of the series.

\section{Docking protocols}

It can be described as two components: a search strategy and an evaluation of docking results (scoring function). The search algorithm generates optimum number of poses including experimentally determined binding mode. The docked poses were scored using Dock score (Accelrys) to find the better docking pose.

\section{Preparation of proteins}

Docking was carried out against caspase-1 protein (1BMQ) which is the possible anticancer target of chalcone derivatives. The selected 
<smiles>[R]c1c([R])c([R])c(C(C)=O)c([R5])c1[R]</smiles>

(5)<smiles>[R1]c1c([R1])c([R1])c(C(C)O)c([R])c1[R5]</smiles>

(6)

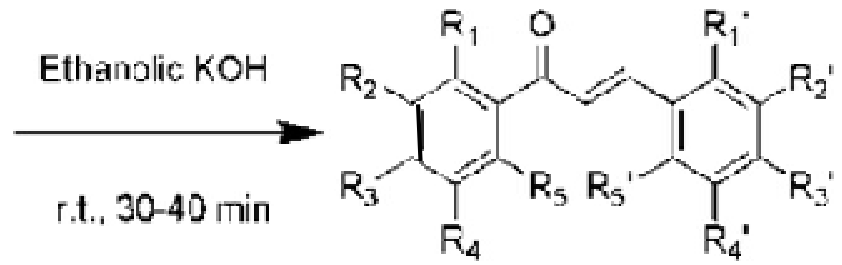

$(7 a-h)$

Figure 1: Scheme of synthesis

target protein was retrieved from Protein Data Bank (PDB) [13].

All ligands, bound water molecules and cofactors were removed from the proteins which were taken in .pdb format. CHARMm force field [14] for minimization of the protein \{(steepest descent (gradient $<0.1$ ) and conjugate gradient algorithms (gradient < 0.01)\}. An appropriate active-site was defined to constitute amino acid residues (PDB: 1BMQ) of $10 \AA$ from the centroid of the bound ligand (if required, partitioned up to 5 levels). Stochastic conformational searching was applied to the ligands with a number higher than the default number of Monte Carlo search steps, to ensure extensive conformational sampling.

\section{Preparation of ligands}

2-D Structures of the ligands were imported by sketching the structures from Chem Draw Ultra 5.0 version [15]. The ligands were minimized by CHARMm Force Field with default setting. 'Prepare Ligands' module was used for the final preparation of ligands for docking run.

\section{Ligand Fit docking}

Ligand Fit (a shape-based method) employs a cavity detection algorithm. A shape comparison filter was combined with Monte Carlo technique to generate ligand conformations which were then docked into the active-site of a protein. Caspase-1 protein was chosen as a target for docking because the sensitivity of U937 monocytic cells to apoptosis induced by etoposide and that the apoptotic process involves the activity of members of the caspase-1 subfamily [16-19].

A grid resolution was set at $0.5 \AA$ (default). The ligand-accessible grid was defined such that the minimum distance between a grid point and the protein is $2.0 \AA$ for hydrogen and $2.5 \AA$ for heavy atoms. The grid extended from the defined active site to a distance of $5 \AA$ in all directions. This grid was used to calculate the non-bonded interactions between the ligands and protein residues. Non-bonded cutoffs were set at $10 \AA$ while using a distance-dependent dielectric constant. Ten iterations of minimization were performed before considering the next iterations and the selected conformers were minimized further to 100 iterations. The ligand conformational space was explored with different initial poses. To avoid identical conformations, RMSD cutoff of 1.5 and a score cutoff of 20 $\mathrm{Kcal} / \mathrm{mol}$ were maintained while recording the final conformations. Docking run generated 10 poses for each ligand and assigned scores.

\section{Synthesis}

\section{General procedure}

Acetophenone (5) $1.1 \mathrm{~mol}$ was dissolved in ethanol with stirring and ethanolic $\mathrm{KOH}(6 \mathrm{~mol})$ was added to this solution at $0{ }^{\circ} \mathrm{C}$. The mixture was stirred for 10-30 min followed by the addition of $1 \mathrm{~mol}$ of the appropriate aldehyde (6). The completion of the reaction was monitored by TLC $\left(\mathrm{CHCl}_{3}: \mathrm{CH}_{3} \mathrm{OH}, 95: 5\right)$ and the disappearance of aldehyde spot was considered as completion of the reaction. The solid was separated from the reaction mixture as a precipitate, filtered and recrystallized using rectified spirit to obtain pure product (7).

\section{Pharmacology}

\section{In vitro cytotoxicity against human cancer cell lines}

The human cancer cell lines were procured from National Cancer Institute, Frederick, U.S.A. The cells were grown in tissue culture flasks in complete growth medium (RPMI-1640 medium with $2 \mathrm{mM}$ glutamine, $\mathrm{pH} 7.4$, supplemented with $10 \%$ fetal calf serum, $100 \mu \mathrm{g} / \mathrm{ml}$ streptomycin and 100 units $/ \mathrm{ml}$ penicillin) in a carbon dioxide incubator $\left(37^{\circ} \mathrm{C}, 5 \% \mathrm{CO}_{2}, 90 \% \mathrm{RH}\right)$. The cells at subconfluent stage were harvested from the flask by treatment with trypsin $\{0.05 \%$ in PBS 
$(\mathrm{pH}$ 7.4) containing $0.02 \%$ EDTA\}. Cells with viability of more than $98 \%$, as determined by trypan blue exclusion, were used for the determination of cytotoxicity. The cell suspension of $1 \times 10^{5}$ cells $/ \mathrm{ml}$ was prepared in complete growth medium.

Stock solutions $\left(2 \times 10^{-2} \mathrm{M}\right)$ of compounds $7 \mathrm{a}-\mathrm{h}$ were prepared in Dimethyl sulfoxide (DMSO). The stock solutions were serially diluted with complete growth medium containing $50 \mu \mathrm{g} / \mathrm{ml}$ of gentamycin to obtain working test solutions of the required concentrations.

In vitro cytotoxicity against five human cancer cell lines was determined using 96-well tissue culture plates. Cell suspension $(100 \mu \mathrm{L})$ was added to each well of the 96-well tissue culture plate. The cells were allowed to grow in carbon dioxide incubator $\left(37^{\circ} \mathrm{C}, 5 \% \mathrm{CO}_{2}, 90 \% \mathrm{RH}\right)$ for $24 \mathrm{~h}$. Test materials in complete growth medium $(100 \mu \mathrm{L})$ were added after $24 \mathrm{~h}$ of incubation to the wells containing cell suspension. The plates were further incubated for $48 \mathrm{~h}$ in a carbon dioxide incubator. The cell growth was stopped by gently layering trichloroacetic acid (50\%, 50 $\mu \mathrm{L}$ ) on top of the medium in all the wells. The plates were incubated at $4{ }^{\circ} \mathrm{C}$ for one hour to fix the cells attached to the bottom of the wells. The liquid of all the wells was gently pipetted out and discarded. The plates were washed five times with distilled water to remove trichloroacetic acid, growth medium, low molecular weight metabolites, serum proteins, etc, and air-dried. The plates were stained with sulforhodamine $B$ dye $(0.4 \%$ in $1 \%$ acetic acid, $100 \mu \mathrm{L})$ for $30 \mathrm{~min}$. The plates were washed five times with $1 \%$ acetic acid and then air-dried. The adsorbed dye was dissolved in Tris- $\mathrm{HCl}$ buffer $(100 \mu \mathrm{l}, 0.01 \mathrm{M}$, $\mathrm{pH} 10.4$ ) and the plates were gently stirred for 10 min on a mechanical stirrer. The optical density (OD) was recorded on an ELISA reader at 540 $\mathrm{nm}$.

The cell growth was determined by subtracting the mean OD value of the respective blank from the mean $O D$ value of the experimental set. Growth (\%) in the presence of the test material was calculated, considering the growth in the absence of any test material as $100 \%$; in turn, growth inhibition (\%) in the presence of the test material was calculated $[11,12]$.

\section{Statistical analysis}

Values reported are the mean values of three experiments each carried in triplicate. $I_{50}$ values were calculated using non-linear regression analysis with the aid of Prism (GraphPad Inc, USA). $P<0.05$ was considered statistically significant in all cases.

\section{RESULTS}

\section{Dock scores}

Energy minimized conformer with best Dock scores (Table 1) was considered for the identification of interacting amino acid residues with ligands.<smiles>[R3]c1c([R1])c([R])c(/C=C/C(=O)c2c([R])c([R])c([R])c([R])c2[R])c([R1])c1[R1]</smiles>

(7a-h)

Table 1: Docking studies of halogenated chalcones

\begin{tabular}{|c|c|c|c|c|c|c|c|c|c|c|c|}
\hline Compound & R1 & $\mathrm{R} 2$ & R3 & $\mathrm{R} 4$ & R5 & R1' & R2' & R3' & R4' & $\mathrm{R}^{\prime}$ & $\begin{array}{l}\text { 1BMQ } \\
\text { Dock } \\
\text { score }\end{array}$ \\
\hline Standard & (MN0601) & & & & & & & & & & 57.5 \\
\hline $7 a$ & $\mathrm{H}$ & $\mathrm{H}$ & $\mathrm{Br}$ & $\mathrm{H}$ & $\mathrm{H}$ & $\mathrm{OCH}_{3}$ & $\mathrm{H}$ & $\mathrm{OCH}_{3}$ & $\mathrm{H}$ & $\mathrm{H}$ & 48.5 \\
\hline $7 b$ & $\mathrm{H}$ & $\mathrm{H}$ & $\mathrm{OC}_{6} \mathrm{H}_{5}$ & $\mathrm{H}$ & $\mathrm{H}$ & $\mathrm{F}$ & $\mathrm{H}$ & $\mathrm{H}$ & $\mathrm{H}$ & $\mathrm{OCH}_{3}$ & 48.6 \\
\hline $7 c$ & $\mathrm{H}$ & $\mathrm{H}$ & $\mathrm{Br}$ & $\mathrm{H}$ & $\mathrm{H}$ & $\mathrm{Cl}$ & $\mathrm{OCH}_{3}$ & $\mathrm{OCH}_{3}$ & $\mathrm{H}$ & $\mathrm{Cl}$ & 51.87 \\
\hline $7 d$ & $\mathrm{H}$ & $\mathrm{H}$ & $\mathrm{OCH}_{3}$ & $\mathrm{H}$ & $\mathrm{H}$ & $\mathrm{Br}$ & $\mathrm{H}$ & $\mathrm{H}$ & $\mathrm{OCH}_{3}$ & $\mathrm{H}$ & 49.62 \\
\hline $7 e$ & $\mathrm{H}$ & $\mathrm{H}$ & $\mathrm{OC}_{6} \mathrm{H}_{5}$ & $\mathrm{H}$ & $\mathrm{H}$ & $\mathrm{H}$ & $\mathrm{H}$ & $\mathrm{OCH}_{3}$ & $\mathrm{H}$ & $\mathrm{F}$ & 48.71 \\
\hline $7 f$ & $\mathrm{H}$ & $\mathrm{H}$ & $\mathrm{Br}$ & $\mathrm{H}$ & $\mathrm{H}$ & $\mathrm{OCF}_{3}$ & $\mathrm{H}$ & $\mathrm{H}$ & $\mathrm{H}$ & $\mathrm{H}$ & 47.3 \\
\hline $7 g$ & $\mathrm{H}$ & $\mathrm{H}$ & $\mathrm{Br}$ & $\mathrm{H}$ & $\mathrm{H}$ & $\mathrm{Br}$ & $\mathrm{H}$ & $\mathrm{H}$ & $\mathrm{OCH}_{3}$ & $\mathrm{H}$ & 46.05 \\
\hline $7 \mathrm{~h}$ & $\mathrm{H}$ & $\mathrm{H}$ & $\mathrm{OCH}_{3}$ & $\mathrm{H}$ & $\mathrm{H}$ & $\mathrm{Cl}$ & $\mathrm{OCH}_{3}$ & $\mathrm{OCH}_{3}$ & $\mathrm{H}$ & $\mathrm{Cl}$ & 49.39 \\
\hline $7 i$ & $\mathrm{H}$ & $\mathrm{H}$ & $\mathrm{H}$ & $\mathrm{H}$ & $\mathrm{OCH}_{3}$ & $\mathrm{H}$ & $\mathrm{OC}_{2} \mathrm{H}_{5}$ & $\mathrm{H}$ & $\mathrm{H}$ & $\mathrm{Cl}$ & 47.3 \\
\hline $7 \mathrm{j}$ & $\mathrm{H}$ & $\mathrm{H}$ & $\mathrm{H}$ & $\mathrm{H}$ & $\mathrm{H}$ & $\mathrm{H}$ & $\mathrm{H}$ & $\mathrm{H}$ & $\mathrm{H}$ & $\mathrm{Br}$ & 38.32 \\
\hline $7 \mathrm{k}$ & $\mathrm{H}$ & $\mathrm{H}$ & $\mathrm{H}$ & $\mathrm{H}$ & $\mathrm{H}$ & $\mathrm{H}$ & $\mathrm{H}$ & $\mathrm{H}$ & $\mathrm{H}$ & $\mathrm{H}$ & 35.89 \\
\hline 71 & $\mathrm{H}$ & $\mathrm{H}$ & $\mathrm{Br}$ & $\mathrm{H}$ & $\mathrm{H}$ & $\mathrm{H}$ & $\mathrm{H}$ & $\mathrm{H}$ & $\mathrm{H}$ & $\mathrm{H}$ & 37.36 \\
\hline $7 m$ & $\mathrm{H}$ & $\mathrm{H}$ & $\mathrm{Cl}$ & $\mathrm{H}$ & $\mathrm{H}$ & $\mathrm{H}$ & $\mathrm{H}$ & $\mathrm{H}$ & $\mathrm{H}$ & $\mathrm{H}$ & 36.62 \\
\hline $7 n$ & $\mathrm{H}$ & $\mathrm{H}$ & $\mathrm{H}$ & $\mathrm{H}$ & $\mathrm{H}$ & $\mathrm{H}$ & $\mathrm{Cl}$ & $\mathrm{H}$ & $\mathrm{H}$ & $\mathrm{H}$ & 37.73 \\
\hline
\end{tabular}




\section{Chemistry}

In the present investigation eight new chalcone derivatives (7a-h) were prepared by the ClaisenSchmidt condensation of different ketones (5) and appropriately substituted aldehydes (6) using reported method (Figure 1, Table 2) [20].

The compounds were re-crystallized using rectified spirit. All the compounds were characterized by detailed spectroscopic (IR, ${ }^{1} \mathrm{H}$ NMR, Mass) analyses.

Table 2: Reaction time and yield of products $7 \mathrm{a}-\mathrm{h}$

\begin{tabular}{lcc}
\hline Compound & $\begin{array}{c}\text { Reaction time } \\
\text { (min) }\end{array}$ & Yield (\%) \\
\hline $7 \mathrm{a}$ & 16 & 94 \\
$7 \mathrm{~b}$ & 24 & 93 \\
$7 \mathrm{c}$ & 12 & 90 \\
$7 \mathrm{~d}$ & 17 & 90 \\
$7 \mathrm{e}$ & 30 & 89 \\
$7 \mathrm{f}$ & 25 & 92 \\
$7 \mathrm{~g}$ & 13 & 82 \\
$7 \mathrm{~h}$ & 28 & 87 \\
\hline
\end{tabular}

1-(4-Bromo-phenyl)-3-(2,4-dimethoxy-phenyl)propenone (7a)

Yellow solid, m.p.: $89-91^{\circ} \mathrm{C}$, IR (KBr) 2852, 1652, 1463, 1453, $967 \mathrm{~cm}^{-1} ;{ }^{1} \mathrm{H} \mathrm{NMR}\left(\mathrm{CDCl}_{3}, 400\right.$ $\mathrm{MHz}, \delta, \mathrm{ppm}) 3.90\left(3 \mathrm{H}, \mathrm{s}, \mathrm{OCH}_{3}\right), 3.86(3 \mathrm{H}, \mathrm{s}$, $\left.\mathrm{OCH}_{3}\right), 6.4(1 \mathrm{H}, \mathrm{d}, \mathrm{Ar}), 6.5(1 \mathrm{H}, \mathrm{dd}, \mathrm{Ar}), 7.4(1 \mathrm{H}$, d, Ar), $7.5(1 \mathrm{H}, \mathrm{d},=\mathrm{CH}-\mathrm{CO}-), 7.6(2 \mathrm{H}, \mathrm{d}, \mathrm{Ar}), 7.8$ $(2 \mathrm{H}, \mathrm{d}, \mathrm{Ar}), 8.0(1 \mathrm{H}, \mathrm{d},=\mathrm{CH}-\mathrm{Ar}) ; \mathrm{MS}(\mathrm{ESI}, \mathrm{m} / \mathrm{z})=$ $347\left(\mathrm{M}^{+}+1,81 \%\right), 349\left(\mathrm{M}^{+}+2,72 \%\right)$.

\section{3-(2-Fluoro-6-methoxy-phenyl)-1-(4-phenoxy- phenyl)-propenone (7b)}

Light yellow solid, m.p.: 92-95 ${ }^{\circ} \mathrm{C}$, IR (KBr) 2951, 2851, 1659, 1462, 1454, $972 \mathrm{~cm}^{-1} ;{ }^{1} \mathrm{H}$ NMR $\left(\mathrm{CDCl}_{3}, 400 \mathrm{MHz}, \delta, \mathrm{ppm}\right) 3.8(3 \mathrm{H}, \mathrm{s}, \mathrm{OMe}), 6.65$ $(2 \mathrm{H}, \mathrm{m}, \mathrm{Ar}), 7.01(4 \mathrm{H}, \mathrm{m}, \mathrm{Ar}), 7.1(1 \mathrm{H}, \mathrm{d},=\mathrm{CH}-$ CO-), 7.2 (4H, m, Ar), $7.8(1 \mathrm{H}, \mathrm{d},=\mathrm{CH}-\mathrm{Ar}), 7.97$ $(2 \mathrm{H}, \mathrm{m}, \mathrm{Ar}) ; \mathrm{MS}(\mathrm{ESI}, \mathrm{m} / \mathrm{z})=350\left(\mathrm{M}^{+}+1\right)(73 \%)$.

\section{1-(4-Bromo-phenyl)-3-(2,6-dichloro-3,4- dimethoxy-phenyl)-propenone (7c)}

Yellow solid, m. p.: $155-157{ }^{\circ} \mathrm{C}$, IR (KBr) 2923, 2853,1664, 1490, 1458, 974, $960 \mathrm{~cm}^{-1}$; ${ }^{1} \mathrm{H}$ NMR $\left(\mathrm{CDCl}_{3}, 400 \mathrm{MHz}, \delta, \mathrm{ppm}\right) 3.7$ (3H, s, OMe), 3.85 $(3 \mathrm{H}, \mathrm{s}, \mathrm{OMe}), 6.9(1 \mathrm{H}, \mathrm{s}, \mathrm{Ar}), 7.56(1 \mathrm{H}, \mathrm{d},=\mathrm{CH}-$ CO-), $7.64(2 \mathrm{H}, \mathrm{d}, \mathrm{Ar}), 7.78(2 \mathrm{H}, \mathrm{d}, \mathrm{Ar}), 7.81(1 \mathrm{H}$, $\mathrm{d},=\mathrm{CH}-\mathrm{Ar}) ; \mathrm{MS}(\mathrm{ESI}, \mathrm{m} / \mathrm{z})=416\left(\mathrm{M}^{+}+1\right)(63 \%)$, $417\left(\mathrm{M}^{+}+2\right)(65 \%)$.
3-(2-Bromo-5-methoxy-phenyl)-1-(4-methoxyphenyl)-propenone (7d)

Yellow solid, m.p.: $121-123{ }^{\circ} \mathrm{C}$, IR (KBr) 2922, 2852, 1658, 1462, 1455, $968 \mathrm{~cm}^{-1}$; ${ }^{1} \mathrm{H}$ NMR $\left(\mathrm{CDCl}_{3}, 400 \mathrm{MHz}, \delta, \mathrm{ppm}\right), 3.85(3 \mathrm{H}, \mathrm{s}, \mathrm{OMe})$, 3.89 (3H, s, OMe), $6.81(1 \mathrm{H}, \mathrm{dd}, \mathrm{Ar}), 6.97(2 \mathrm{H}, \mathrm{d}$, $\mathrm{Ar}), 7.23(1 \mathrm{H}, \mathrm{d},=\mathrm{CH}-\mathrm{CO}-), 7.38(1 \mathrm{H}, \mathrm{d}, \mathrm{Ar}), 7.51$ $(1 \mathrm{H}, \mathrm{d}, \mathrm{Ar}), 8.01(1 \mathrm{H}, \mathrm{d},=\mathrm{CH}-\mathrm{Ar}), 8.06(2 \mathrm{H}, \mathrm{d}, \mathrm{Ar})$ ; MS $(\mathrm{ESI}, \mathrm{m} / \mathrm{z})=347\left(\mathrm{M}^{+}+1\right)(75 \%), 349\left(\mathrm{M}^{+}+2\right)$ (77\%).

\section{3-(2-Fluoro-4-methoxy-phenyl)-1-(4-phenoxy- phenyl)-propenone (7e)}

Yellow solid, m.p.: $125-127{ }^{\circ} \mathrm{C}$, IR (KBr) 2972, 2942, 2881, 2837, 1680, 1657, 1585, 1488, 1469, $988 \mathrm{~cm}^{-1} ;{ }^{1} \mathrm{H}$ NMR $\left(\mathrm{CDCl}_{3}, 400 \mathrm{MHz}, \delta\right.$, ppm), 3.85 (3H, s, OMe), $6.65(2 \mathrm{H}, \mathrm{m}, \mathrm{Ar}), 7.01$ $(4 \mathrm{H}, \mathrm{m}, \mathrm{Ar}), 7.1(1 \mathrm{H}, \mathrm{d},=\mathrm{CH}-\mathrm{CO}-), 7.2(4 \mathrm{H}, \mathrm{m}$, $\mathrm{Ar}), 7.8(1 \mathrm{H}, \mathrm{d},=\mathrm{CH}-\mathrm{Ar}), 7.94(2 \mathrm{H}, \mathrm{m}, \mathrm{Ar}) ; \mathrm{MS}$ $(\mathrm{ESI}, \mathrm{m} / \mathrm{z})=349\left(\mathrm{M}^{+}+1\right)(62 \%)$.

\section{1-(4-Bromo-phenyl)-3-(2-trifluoromethoxy- phenyl)-propenone (7f)}

Yellow solid, m.p.: $180-183{ }^{0} \mathrm{C}$, IR (KBr) 2852, $1654,1596,1552,1462,1455,1376,1306$, 1154, 1078, $966 \mathrm{~cm}^{-1} ;{ }^{1} \mathrm{H}$ NMR $\left(\mathrm{CDCl}_{3}, 400\right.$ $\mathrm{MHz}, \delta, \mathrm{ppm}), 7.13(1 \mathrm{H}, \mathrm{d}, \mathrm{Ar}), 7.17(1 \mathrm{H}, \mathrm{d},=\mathrm{CH}-$ CO), 7.38 (1H, m, Ar), 7.47 (2H, m, Ar), $7.57(1 \mathrm{H}$, $\mathrm{d}$, =CH-Ar), $7.8(2 \mathrm{H}, \mathrm{m}, \mathrm{Ar}), 7.95(2 \mathrm{H}, \mathrm{m}, \mathrm{Ar})$; MS $(E S I, m / z)=371\left(M^{+}+1\right)(62 \%), 373\left(\mathrm{M}^{+}+2\right)$ (60\%).

\section{3-(2-Bromo-5-methoxy-phenyl)-1-(4-bromo- phenyl)-propenone (7g)}

Yellow solid, m.p.: 192-194 ${ }^{0} \mathrm{C}$, IR (KBr) 2842, 1678, 1582, 1481, 1394, 1245, 1072, 1014, 817 $\mathrm{cm}^{-1} ;{ }^{1} \mathrm{H} \mathrm{NMR}\left(\mathrm{CDCl}_{3}, 400 \mathrm{MHz} \delta, \mathrm{ppm}\right), 3.85$ $(3 \mathrm{H}, \mathrm{s}, \mathrm{OMe}), 6.81(1 \mathrm{H}, \mathrm{dd}, \mathrm{Ar}), 6.97(2 \mathrm{H}, \mathrm{d}$, $\mathrm{Ar}), 7.23(1 \mathrm{H}, \mathrm{d},=\mathrm{CH}-\mathrm{CO}-), 7.38(1 \mathrm{H}, \mathrm{d}, \mathrm{Ar}), 7.51$ (1H, d, Ar), 8.01 (1H, d, =CH-Ar), $8.06(2 \mathrm{H}, \mathrm{d}, \mathrm{Ar})$ ; MS $(\mathrm{ESI}, \mathrm{m} / \mathrm{z})=394\left(\mathrm{M}^{+}+1\right)(66 \%), 396\left(\mathrm{M}^{+}+2\right)$ (64\%).

\section{3-(2,6-Dichloro-3,4-dimethoxy-phenyl)-1-(4- methoxy-phenyl)-propenone (7h)}

Yellow solid, m.p.: $131-133{ }^{\circ} \mathrm{C}$, IR (KBr) 2945, 2877, 2837, 1669, 1606, 1490, 1434, $961 \mathrm{~cm}^{-1}$; ${ }^{1} \mathrm{H}$ NMR $\left(\mathrm{CDCl}_{3}, 400 \mathrm{MHz}, \delta, \mathrm{ppm}\right), 3.57(3 \mathrm{H}, \mathrm{s}$, OMe), 3.7 (3H, s, OMe), 3.85 (3H, s, OMe), 6.9 $(1 \mathrm{H}, \mathrm{s}, \mathrm{Ar}), 7.56(1 \mathrm{H}, \mathrm{d},=\mathrm{CH}-\mathrm{CO}-), 7.59(2 \mathrm{H}, \mathrm{d}$, $\mathrm{Ar}), 7.78(2 \mathrm{H}, \mathrm{d}, \mathrm{Ar}), 7.81(1 \mathrm{H}, \mathrm{d},=\mathrm{CH}-\mathrm{Ar})$; MS $(\mathrm{ESI}, \mathrm{m} / \mathrm{z})=368\left(\mathrm{M}^{+}+1\right)(82 \%)$. 


\section{Pharmacology}

The in vitro cytotoxic activity of compounds $7 \mathrm{a}-\mathrm{h}$ are reported in terms of \% inhibitory concentration $\left(\mathrm{IC}_{50}\right)$ and the data are shown in Table 3.

The synthesized compounds showed good anticancer activity against colon and ovarian cancer cell lines. The results of anticancer activity revealed that in the case of colon cell line (COLO-205), the maximum inhibition $71 \%$ (50 $\mu \mathrm{M})$ was observed for $7 \mathrm{~b}$ with $\mathrm{IC}_{50}=49.9$ followed by $37 \%$ and $36 \%$ for $7 \mathrm{~d}$ and $7 \mathrm{a}$ at the same concentration. For ovarian cancer cell line (OVCAR-5) also the maximum inhibition $42 \%$ $(50 \mu \mathrm{M})$ and $39 \%(10 \mu \mathrm{M})$ were observed for $7 \mathrm{~d}$ $\left(\mathrm{IC}_{50}=66.6\right)$, followed by $38 \%$ at the same concentration for $7 \mathrm{a}$.

Against liver cell line (HEP-2) the maximum inhibition of $32 \%(50 \mu \mathrm{M})$ and $31 \%(50 \mu \mathrm{M})$ for
$7 b$ and $7 d$ were observed. The inhibitory effect on CNS was also evaluated using (IMR-32) cell lines. In this case maximum inhibition of $35 \%$ for $7 \mathrm{~d}$ and $30 \%$ for $7 \mathrm{c}(50 \mu \mathrm{M})$ were observed. In the case of prostate cancer cell line (PC-3) none of the compounds showed significant activity. Compounds $7 \mathrm{~b}$ and $7 \mathrm{~d}$, however, exhibited $11 \%$ inhibition at $50 \mu \mathrm{M}$.

\section{DISCUSSION}

In the present investigation, in silico docking studies were performed using the crystal structure of interleukin-1beta convertase (caspase-1) (PDB ID: 1BMQ) [13, 21] to recognize the hypothetical binding mode of the ligands with the receptor in order to design a series of novel halogenated chalcone derivatives (7a-h) as possible anticancer agents. To investigate the ability of molecular docking to

Table 3: In vitro cytotoxicity including $\mathrm{IC}_{50}$ values of compounds $7(\mathrm{a}-\mathrm{h})$ against different human cancer cell lines

\begin{tabular}{|c|c|c|c|c|c|c|}
\hline \multirow[t]{2}{*}{ Compound } & \multirow{2}{*}{$\begin{array}{c}\text { Conc. I } \\
\text { IC } 50(\mu \mathrm{M})\end{array}$} & \multicolumn{5}{|c|}{$\%$ Growth inhibitiona / IC50 b } \\
\hline & & $\mathrm{PC}=3$ & Colo-205 & UVCAR-5 & Hep-2 & TIMIR-32 \\
\hline \multirow[t]{3}{*}{$7 a$} & 10 & 0 & 20 & 22 & 9 & 0 \\
\hline & 50 & 8 & 36 & 38 & 19 & 0 \\
\hline & IC50 & $>100$ & $>100$ & $>100$ & $>100$ & $>100$ \\
\hline \multirow[t]{3}{*}{$7 b$} & 10 & 2 & 20 & 33 & 22 & 9 \\
\hline & 50 & 11 & 71 & 34 & 32 & 25 \\
\hline & IC50 & $>100$ & 49.9 & $>100$ & $>100$ & $>100$ \\
\hline \multirow[t]{3}{*}{ 7c } & 10 & 1 & 32 & 11 & 16 & 8 \\
\hline & 50 & 3 & 33 & 21 & 19 & 30 \\
\hline & IC50 & $>100$ & $>100$ & $>100$ & $>100$ & $>100$ \\
\hline \multirow[t]{3}{*}{$7 d$} & 10 & 6 & 18 & 39 & 7 & 9 \\
\hline & 50 & 11 & 37 & 42 & 31 & 35 \\
\hline & IC50 & $>100$ & $>100$ & 66.56 & $>100$ & $>100$ \\
\hline \multirow[t]{3}{*}{$7 e$} & 10 & 2 & 13 & 36 & 13 & 9 \\
\hline & 50 & 2 & 18 & 37 & 15 & 13 \\
\hline & IC50 & $>100$ & $>100$ & $>100$ & $>100$ & $>100$ \\
\hline \multirow[t]{3}{*}{$7 f$} & 10 & 2 & 19 & 16 & 5 & 11 \\
\hline & 50 & 5 & 22 & 24 & 7 & 20 \\
\hline & IC50 & $>100$ & $>100$ & $>100$ & $>100$ & $>100$ \\
\hline \multirow[t]{3}{*}{$7 g$} & 10 & 0 & 6 & 24 & 7 & 0 \\
\hline & 50 & 6 & 10 & 34 & 11 & 20 \\
\hline & IC50 & $>100$ & $>100$ & $>100$ & $>100$ & $>100$ \\
\hline \multirow[t]{3}{*}{$7 \mathrm{~h}$} & 10 & 1 & 7 & 20 & 15 & 0 \\
\hline & 50 & 1 & 9 & 22 & 23 & 9 \\
\hline & IC50 & $>100$ & $>100$ & $>100$ & $>100$ & $>100$ \\
\hline Adriamycin & 10 & 73 & 81 & 79 & 86 & 47 \\
\hline Paclitaxel & 10 & 10 & 78 & 53 & 54 & 21 \\
\hline $5 \mathrm{FU}$ & 2 & 9 & 39 & 32 & 10 & 11 \\
\hline
\end{tabular}

a inhibition caused by the compounds and standard drugs at various concentrations.

${ }^{b} 50 \%$ inhibitory concentration represents the mean from dose response curves of number of experiments 
reproduce an experimentally observed ligand binding mode, the co-crystallized ligand MNO 601 (3s)-n-methanesulfonyl-3-(\{1-[n-(2-naphtoyl)I-valyl]-I-prolyl\}amino)-4-oxobutanamide has been used as reference ligand $\left(\mathrm{IC}_{50}=38 \mathrm{nM}\right)$.

Subsequently, MNO 601 was docked back into its binding site of the crystal structure of the caspase-1 using Discovery Studio, Version 21 (2007), Accelrys Inc. [10].

The docking pose closely resembled the cocrystallized conformation. The naphthyl group showed significant $\pi$-stacking interaction with His342 and Arg383 that was proposed to be crucial for having the enhanced binding affinity of the co-crystal ligand [21]. The carbonyl oxygen atom formed a strong hydrogen bond with the side chains of $\operatorname{Arg} 341$ at a distance $2.70 \AA$. Moreover, the nitrogen atom of the amide group seems to be deprotonated and have a salt bridge with Arg341. The oxygen atom of methanesulfonaminocarbonyl group was found to form a hydrogen bond with the nitrogen atom of guanidine moiety of Arg341 and pyrazole ring of His237 at a distance of 2.47 and $3.10 \AA$ respectively. The aldehyde group of the ligand formed strong covalent bond with the sulphur atom of Cys285. All the designed compounds were docked following the same docking protocol and analyzed for their interactions with the binding site (active site) amino acids of caspase1. Binding orientation of the most active compound, $\mathbf{7 b}$, is also presented (Figure 2).

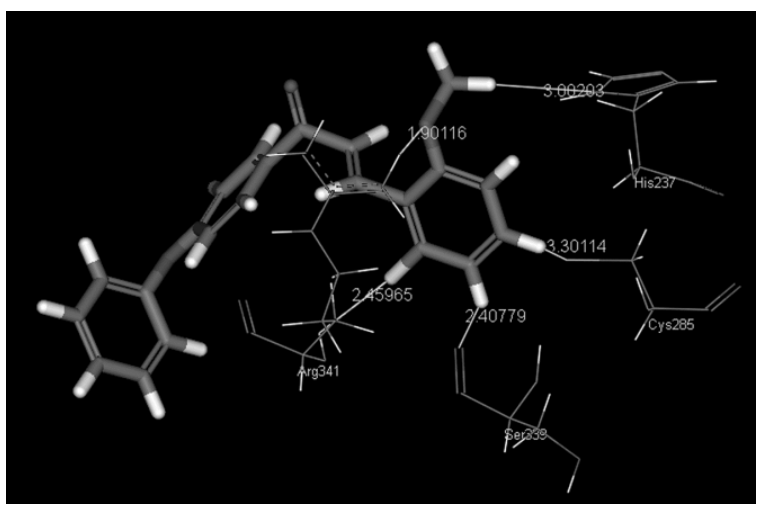

Figure 2: Binding orientation of the most active compound $(7 b)$

The designed compounds were found to accommodate the binding pocket of the receptor showing the important interactions with the crucial amino acid residues. In particular, the $O$ methoxy moiety was found to form a significant hydrogen bond interaction with His237 and Arg341 at a distance of $3.0 \AA$ and $1.9 \AA$ respectively. Interestingly, no salt bridge formation was observed with the designed compounds. The fluoro group of the phenyl ring formed crucial hydrogen bond with Arg341. Weak hydrogen bond is also observed between phenyl ring and Cys 285. Additional interaction with Ser339 was also seen.

All the compounds with predicted good binding affinities (docking score) as compared to the reference standard (MNO 601) (Table-1) were selected for synthesis (Figure 1, Table 2) and later on evaluated for anticancer activity. The synthesized compounds showed good anticancer activity against colon and ovarian cancer cell lines. The in vitro results (Table 3 ) showed that these molecules may potentially be used for targeting caspase- 1 for the management of cancer expressing caspase dependent apoptosis pathway. Therefore, the synthesized compound, 3-(2-Fluoro-6-methoxy-phenyl)-1-(4-phenoxy-

phenyl)-propenone (7b) may possess essential candidature to be studied in vivo for proving anticancer efficacy.

\section{CONCLUSION}

The new halogenated chalcones designed and synthesized, based on the bioisosteric replacement of a known ligand, were well docked onto the binding pocket of caspase enzyme and interacted with crucial amino acid residues. Compounds $7 \mathrm{a}, 7 \mathrm{~b}, 7 \mathrm{~d}$ are active on colon cancer line COLO-205, and $7 \mathrm{~b}$ showed $\mathrm{IC}_{50}$ value of 49.9. These molecules may serve as useful 'lead' compounds for further development.

\section{ACKNOWLEDGEMENT}

The authors thank the management of Chandigarh Group of Colleges, Landran, India, for encouragement and providing the necessary facilities for carrying out this work. We gratefully acknowledge the Chairperson, University Institute of Pharmaceutical Sciences and UGC Center of Advanced Study (UGC-CAS) in Pharmaceutical Sciences, Panjab University, Chandigarh, India, for their support by extending their lab facilities and required software and hardware for docking studies. We also thank the Director, Indian Institute of Integrative Medicine, Jammu, India, for making available facilities to conduct the anticancer studies.

\section{REFERENCES}

1. Park EJ, Park HR, Lee JS, Kim. Licochalcone A: an inducer of cell differentiation and cytotoxic agent from Pogostemon cablin. Planta Med 1998; 64 (5): 464-466.

2. Ko HH, Tsao LT, Yu KL, Liu CT, Wang JP, Lin CN. Structure-activity relationship studies on chalcone derivatives. The potent inhibition of chemical mediators release. Bioorg Med Chem 2003; 11(1): 105-111.

Trop J Pharm Res, January 2014;13 (1): 
3. Nielsen SF, Christensen SB, Cruciani G, Kharazmi A, Liljefors T. Antileishmanial chalcones: Statistical design, synthesis and three-dimentional quantitative structure-activity relationship analysis. $J$ Med Chem 1998; 41(24): 4819-4832.

4. Cabrera M, Simoens M, Falchi G, Lavaggi ML, Piro OE, Castellano EE, Vidal A, Azqueta A, Monge A, de Ceráin AL, Sagrera G, Seoane G, Cerecetto $H$ González M. Synthetic chalcones, flavanones, and flavones as antitumoral agents: biological evaluation and structure-activity relationships. Bioorg Med Chem 2007; 15: 3356-3367.

5. Ducki S, Rennison D, Woo M, Kendall A, Chabert JF, McGown AT, Lawrence NJ. Combretastatin-like chalcones as inhibitors of microtubule polymerization: synthesis and biological evaluation of antivascular activity. Bioorg Med Chem 2003; 17: 7698-7710.

6. Yang Y, Xia P, Bastow KF, Nakanishi Y, Lee KH. Antitumor agents. Part 202: novel 2'-amino chalcones: design, synthesis and biological evaluation. Bioorg Med Chem Lett 2000; 10: 699701.

7. Boumendjel A. 4-Hydroxy-6-methoxyaurones with highaffinity binding to cytosolic domain of $P$ glycoprotein. Chem Pharm Bull 2002; 50: 854-856.

8. Bois F, Beney C, Boumendjel A, Mariotte AM, Conseil G, Pietro $A D$. Halogenated chalcones with high-affinity binding to p-glycoprotein: potential modulators of multidrug resistance. J Med Chem 1998; 41: 4161 4164.

9. Ivanova $A B$. Comparative study on the $m d r$ reversal effects of selected chalcones. Int J Med Chem 2011; Article ID 530780: 1-7.

10. Discovery Studio, Version 21 (2007), Accelrys Inc: San Diego, CA, USA.

11. Monks A, Scudiero D, Skehan P, Shoemaker R, Paull K, Vistica $D$, Hose $C$, Langley J, Cronise $P$, VaigroWolff A, Gray-Goodrich M, Campbell H, Mayo J and Boyd M. Feasibility of a high-flux anticancer drug screen using a diverse panel of cultured human tumor cell lines J Natl Cancer Inst 1991; 83 : 757-766.
12. Skehan $P$, Storeng $R$, Scudiero $D$, Monks $A$, McMahon $J$, Vistica D, Warren JT, Bokesch H, Kenney S, Boyd MR. New colorimetric Cytotoxic Assay for Anticancer-Drug Screening. J Natl Cancer Inst 1990; 82: 1107-1112.

13. Okamoto $Y$, Anan $H$, Nakai E, Morihira K, Yonetoku $Y$, Kurihara H, Sakashita H, Terai Y, Takeuchi M, Shibanuma $T$, Isomura $Y$. Peptide based interleukin-1 beta converting enzyme (ICE) inhibitors: synthesis, structure activity relationships and crystallographic study of the ICE-inhibitor complex. Chem Pharm Bull 1999; 47: 11-21.

14. Brooks BR, Bruccoleri RE, Olafson $D$, Swaminathan $S$, Karplus M. CHARMm. A program for macromolecular energy, minimization and dynamics calculations. J Comput Chem 1983; 4:187-217.

15. Chem Draw Ultra-version, CambridgeSoft Inc, Cambridge, USA, 2007; 50.

16. McGann MR, Almond HR, Nicholls A, Grant JA, Brown FK. Gaussian docking functions. Biopolymers 2003; 68: 76-90.

17. Stalh $M$, Rarey M. Detailed analysis of scoring functions for virtual screening. J Med Chem 2001; 44: $1035-$ 1042.

18. Gehlhaar DK, Verkhivker GM, Rejto PA, Sherman CJ, Fogel DB, Fogel LJ, Freer ST. Molecular recognition of the inhibitor AG-1343 by HIV-1 protease: conformationally flexible docking by evolutionary programming. Chem Biol 1995; 2: 317-324.

19. Vigers GP, Rizzi JP. Multiple Active Site Corrections for Docking and Virtual Screening. J Med Chem 2004; 47: 80-89.

20. Matteson DS. (Alkoxyalkyl) boronic ester intermediates for asymmetric synthesis. Organometallics 1996, 15: 152-163.

21. Keith PW, Jo-Anne FB, John AT. Structure and mechanism of interleukin-1 $\beta$ converting enzyme. Nature 1994, 370: $270-275$. 